\title{
PEMIKIRAN SUFISTIK DAN TOLERANSI BERAGAMA KH. SHOLEH BAHRUDDIN DI PESANTREN NGALAH PASURUAN
}

\author{
Muhammad Muntahibun Nafis \\ Institut Agama Islam Negeri Tulungagung, Indonesia \\ E-mail: muntahibunnafis@gmail.com \\ Muhammad Ainun Najib \\ Institut Agama Islam Negeri Tulungagung, Indonesia \\ E-mail: muhammadainunajib@gmail.com
}

\begin{abstract}
Sufism and tariqa (Sufi order) play a significant role in building and enhancing mutual-peaceful dialogue between Islam and other religions and cultures. The Sufis establish cooperation with followers of other religions. This is because Sufism holds a moderate view and understanding of Islamic doctrines. Sufism is, therefore, not limited only to spirituality and the mystical realm, but it is also able to create a harmonious relationship among humans and between humans and nature. This article seeks to present a related study on the doctrine of religious tolerance within Sufism promulgated by KH. Sholeh Bahruddin, the headmaster of Pesantren (Islamic boarding school) Ngalah Pasuruan East Java. Kiai Sholeh sees Sufism as the main foundation of religious tolerance. As the murshid of the Tarekat Qādirīyah wa Naqsabandīyah Mujaddadīyah Khālidīyah Kiai Sholeh has intensively cultivated Islam rabmah li al-'älamin in the pesantren he leads. This doctrine emphasizes that Islam rabmab li al'álamin perceives all human beings as kabeh dulur (all are brothers) regardless of their religious and social background and political preference. Through the concept of kabeh dulur, Kiai Sholeh builds human relationships with anyone, including people of different faiths and beliefs.
\end{abstract}

Keywords: Sufism; pesantren; kiai; religious tolerance; Kabeh Dulur.

\section{Pendahuluan}

Salah satu permasalahan sekaligus kekayaan bangsa ini adalah pluralitas agama dan keyakinan. Negara Indonesia yang berdasarkan 
Pancasila menjamin hak-hak beragama dan berkeyakinan setiap warga negara. Beragama merupakan sebuah hak asasi yang sangat privat bagi individu, sehingga tidak bisa dipaksakan dan dicampuri oleh orang lain. Sebab beragama adalah sebuah proses pengalaman batin seseorang yang tidak dapat diintervensi oleh siapapun. Substansi agama terletak dalam hubungan transendental dengan Tuhan.

Keberadaan agama-agama menjadi problem yang tidak mudah diselesaikan di Indonesia. Karel Steenbrink memandang unsur agama di Indonesia merupakan penghalang bagi kemajuan. ${ }^{1}$ Untuk mengatur pluralitas agama tersebut, pemerintah mengaturnya dalam Undangundang dan Surat Keputusan Bersama (SKB) menteri. Ada dugaan kuat bahwa pemerintah mengidap ketakutan yang luar biasa terhadap pluralitas agama. Karena itu, tidak berlebihan, bila ada kesan perekayasaan kerukunan umat beragama. ${ }^{2}$ Pemerintah memang berkewajiban untuk mengatur pluralitas agama dengan berbagai pertimbangan. Tidak terbayangkan bila pluralitas agama tidak diatur dengan baik.

Trilogi kerukunan umat beragama yang dikampanyekan rezim Orde Baru tidak berdampak mendalam dalam kehidupan beragama. Harapan terciptanya kerukunan memang masih ada. Namun secara faktual kerukunan hidup antarumat beragama di Indonesia masih menghadapi banyak permasalahan. Berdasarkan Laporan Tabun Kehidupan Beragama di Indonesia (2010) yang diterbitkan oleh Center for Religious and Cross-Cultural Studies (CRCS) Universitas Gadja Mada Yogyakarta, ada dua masalah yang menjadi tantangan dalam menciptakan kerukunan dan kebebasan dalam beragama, yaitu masalah rumah ibadah dan penyesatan. Tercatat sebanyak 39 masalah kerukunan hidup antarumat adalah masalah rumah ibadah, di mana 32 kasus diantaranya menyangkut hubungan antarumat beragama. ${ }^{3}$ Terorisme adalah satu di antara bentuk disharmoni hubungan antarumat beragama itu. Kasus teror yang paling aktual adalah pengemboman tiga gereja di Surabaya pada 13 Mei 2018. Peristiwa teror itu menyebabkan lebih dari sepuluh orang meninggal dan puluhan jemaat Gereja terluka serta beberapa titik bangunan Gereja

1 Karel Steenbrink, "Indonesia: Too Much Religion" Basis, No. 01-02, JanuariFebruari 2004, 44.

2 St. Sunardi, "Rekayasa Kerukunan Umat Beragama," Basis, No. 01-02, JanuariFebruari 2004.

3 Zainal Abidin Bagir, dkk, Laporan Tabun Kebidupan Beragama di Indonesia (Yogyakarta: CRCS UGM, 2011), 33-34. 
rusak. Aksi biadab yang dilakukan oleh pelaku yang masih satu keluarga ini diduga kuat dilakukan orang yang terpapar ideologi terorisme-keagamaan.

Kekerasan memang seumur manusia. Dalam sejarah, awal kekerasan yang terjadi antarumat manusia konon dimulai dari kisah pertikaian antara Qabil dan Habil. Pembunuhan terhadap saudara yang melibatkan anak Nabi Adam itu dianggap sebagai permulaan dari peristiwa kekerasan antarmanusia yang terjadi di muka bumi. ${ }^{4}$ Menurut Daniel Dhakidae sebagaimana dikutip oleh Abd. A'la, ${ }^{5}$ pada zaman Romawi Kuno, sejarah umat manusia disebut sebagai sejarah perang. Karena pada masa itu banyak terjadi kekerasan oleh sebab perang. Tragisnya, perang masih tetap berlaku dan sealalu mewarnai sejarah peradaban manusia hinnga kini. ${ }^{6}$ Perang dan tindakan lain yang sejenis, seperti kekerasan, penindasan, dan kerusuhan dengan berbagai faktor penyebabnya, seakan menjadi bagian yang tidak terpisahkan dalam kehidupan umat manusia. Padahal tidak ada agama apapun yang mendorong dan menganjurkan pengikutnya untuk melakukan kekerasan (violence) terhadap pengikut agama lain (the other) di luar agama dan kelompoknya. Namun dalam tataran faktual, masih banyak dijumpai tindak kekerasan yang dilakukan oleh sebagian masyarakat bahkan dengan dalih agama. ${ }^{7}$ Dari sini maka toleransi beragama menjadi tindakan nyata dalam upaya membangun kehidupan beragama yang lebih harmonis.

\section{Tasawuf sebagai Fondasi Utama Toleransi}

Sufisme atau tasawuf adalah suatu situasi pengalaman spiritual yang pararel dengan aliran utama kesadaran Islam yang diturunkan dari wahyu profetik dan yang dipahami dalam syariah dan teologi. J. Spencer Trimingham menyatakan bahwa mistisisme adalah metode tertentu dalam penghampiran kepada realitas (haqiqah), sebuah term

\footnotetext{
4 Abdul Munir Mulkhan, Membongkar Praktek Kekerasan: Menggagas Kultur NirKekerasan (Yogyakarta: Sinergi Press, 2002), 77.

5 Abd A'la, Melampui Dialog Agama (Jakarta: Kompas, 2002), iix.

${ }^{6}$ Prinsip yang masih dipegangi itu adalah Civis Pacem, Para Bellum; jika anda ingin damai, siaplah untuk berperang. Prinsip ini juga dijelaskan oleh seorang tokoh sosiolog terkemuka yaitu Georg Simmel. Lihat dalam Samsul Arifin, Merambah Jalan Baru dalam Beragama: Rekonstruksi Kearifan Perenial Agama dalam Masyarakat Madani dan Pluralitas Bangsa (Yogyakarta: ITTAQA Press, 2001), 56.

${ }^{7}$ M. Amin Abdullah, "Menuju Pendidikan Islam Pluralis", Taswirul Afkar, edisi No 11,9 .
} 
khusus sufisme yang lain), dengan memanfaatkan fakultas-fakultas spiritual dan emosional yang umumnya terpendam. Seyyed Hossein Nasr menyatakan bahwa "sufisme merupakan puncak esensi spiritual dan dimensi esoteris Islam", yang menarik perhatian hampir semua pihak yang merasa perlu untuk menemukan kembali pusat eksistensi. ${ }^{8}$

Dewasa ini semakin banyak orang-orang Barat yang tertarik untuk mempelajari sufisme dalam Islam yang dianggap dapat memberikan jawaban-jawaban terhadap ragam kebutuhan intelektual yang paling mendesak pada saat ini. Bahwa hal-hal spiritual yang terkandung di dalam sufisme itulah yang lebih dapat mengobati dahaga manusiamanusia yang mencari Tuhan. Nasr mengingatkan bahwa sufisme janganlah diklasifikasikan dengan tradisi-tradisi integral lainnya seperti Hinduisme dan Buddhisme, karena ia adalah bagian dari Islam dan bukan sebuah tradisi yang berdiri sendiri. Islam dapat dikatakan sebagai sebuah tradisi seperti Kristen dan Buddhisme, tetapi sufisme harus dipahami sebagai sebuah bentuk dimensi dari tradisi Islam. ${ }^{9}$

Tasawuf merupakan implementasi salah satu tiga pilar pokok ajaran Islam, ibsän. Tasawuf mengajarkan spiritualitas yang berusaha diwujudkan dalam kehidupan bersama di tengah masyarakat. Mewujudkan tatanan masyarakat yang damai dan memberikan ruang yang kondusif bagi seseorang mengamalkan ajaran agamanya merupakan salah satu cita-cita semua umat manusia, dan hal ini pun diupayakan oleh agama melalui ajarannya. Melalui tasawuf, Islam berusaha untuk mengajak umatnya melakukan segala macam kebajikan dalam kehidupan (ibsän).

Dalam perspektif sosiologis, manusia menampakkan agama dalam bentuk yang tidak sebenarnya. Manusia kadang menampilkan wajah agama yang garang, seram, menakutkan, dan penuh dengan lembar kekerasan. Dalam arti yang lain, wajah menyeramkan agama yang akhirnya menimbulkan konflik tersebut tanpa disadari malah menodai citra kemanusiaan dan agama itu sendiri. Konflik atas nama agama selama ini sering terlihat di masyarakat. Bisa saja konflik ini tidak murni karena agama, tetapi ditunggangi berbagai kepentingan politik dan ekonomi. Tetapi alasan tersebut tentunya masih bisa ditelusuri secara mendalam, benarkah manusia yang memiliki hati nurani dan nilai agama dengan mudahnya melakukan berbagai bentuk kekerasan

${ }^{8}$ Robby H. Abror, Tasawuf Sosial: Membeningkean Kebidupan dengan Kesadaran Spiritual (Yogyakarta: AK Gorup- Fajar Pustaka Baru, 2002), 11.

${ }^{9}$ Ibid., 12. 
tersebut, padahal semua agama mengajarkan kebaikan bukan kekerasan.

Teori psikoanalisis memandang konflik dan kekerasan agama tersebut terjadi karena manusia memiliki unsur ego. Ego menggambarkan pengalaman seseorang mengenai dirinya sendiri atau konsepsi seseorang mengenai dirinya sendiri sehingga wajar jika kepentingan individu seringkali mendominasi pertimbangan dalam berperilaku dan bertindak. Perilaku individu dan sosial yang dipaparkan tersebut tidak dapat lepas dari pengalaman beragama yang berpangkal pada pemahaman seseorang terhadap Tuhannya. Jika muncul ketakharmonisan hubungan antar-pemeluk agama atau intern agama, maka hal itu lebih banyak disebabkan oleh ekspresi dari pengalaman subjektif seseorang terhadap Tuhan. Dengan kata lain konflik antar-pemeluk agama boleh jadi didasarkan pada keinginan untuk melakukan pembelaan terhadap Tuhan yang diyakini masingmasing pemeluk agama. Sebaliknya ekspresi pengalaman beragama yang santun dan penuh kearifan juga merupakan hasil dari pemahaman untuk Tuhan yang menganjurkan hubungan berdasarkan kearifan. ${ }^{10}$

Pemahaman terhadap pengalaman beragama dan ekspresinya dalam bentuk perilaku individu dan kehidupan bersama menjadi signifikan bagi siapa saja yang menginginkan suasana pengalaman agama masing individu yang saleh dan pada saat yang bersamaan juga santun terhadap orang lain dalam kehidupan bersama. William James dalam bukunya The Varieties of Religious Experience-sebagaimana dikutip Abdul Jamil — memaknai istilah pengalaman beragama sebagai pijakan untuk menguraikan fenomena tentang realitas gaib, yang dengannya manusia mengadakan hubungan dalam bermacam-macam bentuk. Pengalaman beragama pada akhirnya menjadi bahasan berbagai disiplin ilmu, di antaranya adalah ilmu jiwa agama dan sosiologi agama. Dalam ilmu jiwa agama, pengalaman beragama menyangkut realitas empiris yang ditampilkan melalui perilaku nyata pada orang beragama. Sedangkan menurut kacamata sosiologi agama, pengalaman beragama akan terekspresikan dalam bentuk kolektif oleh umat beragama. ${ }^{11}$

10 Amin Syukur dkk, Islam Agama Santun (Semarang: IAIN Walisongo- RaSAIL Media Group, 2011), 25.

${ }^{11}$ Ibid., 26. 
Dengan adanya berbagai pandangan terhadap pengalaman beragama tersebut menjadi bukti akan semangat manusia untuk menyingkap "tabir" misteri "dunia atau realitas lain" yang tidak semua orang mampu dengan mudah untuk menyingkapnya. Penyingkapan tersebut diupayakan seobjektif mungkin, sehingga akan mampu memberikan "data" riil yang pada akhirnya akan memberikan sumbangsih bagi manusia itu sendiri. Terminologi "pengalaman" akan memberikan dua makna yang terkandung di dalamnya, yakni: Pertama, menunjukkan pengertian praktis yang diperoleh melalui percobaan atau eksperimen, sehingga empiris merupakan alat untuk merekam pengalaman tersebut. Kedua, merupakan hasil pengetahuan yang didapatkan oleh seseorang. Jika pengertian dasar ini dikaitkan dengan agama, maka ia akan memiliki dua pengertian yaitu adanya pengetahuan dan kesadaran akan dunia lain dan perilaku beragama individu maupun kolektif yang merupakan bukti empiris dari pengalaman spiritual. ${ }^{12}$

Setidaknya ada dua cara untuk memahami pengalaman beragama ini: Pertama, menggunakan deskripsi sejarah, sekte atau aliran pemikiran keagamaan yang diperlihatkan oleh setiap pemeluknya. Kedua, berangkat dari wilayah di mana pengalaman perorangan itu berlangsung. Betapapun kaum materialisme berusaha menolak kebenaran agama, tetapi sejarah agama memperlihatkan dinamika kehidupan umat manusia yang tak lepas dari agama dan kepercayaan terhadap "dunia lain". Hal ini menjadi bukti empiris yang tidak dapat disangkal lagi. Cara pendekatan pengalaman beragama yang bertitik tolak dari lingkungan pengalaman perorangan itu berlangsung, memang dapat menimbulkan anggapan adanya subjektivisme, karena kata "pengalaman" lebih mengacu pada perbuatan manusia dan bukan perbuatan Tuhan. Dengan kata lain, "pengalaman" cenderung memusatkan subjek yang mengalami daripada objek yang dialami. ${ }^{13}$

Keadaaan semacam ini tidak dapat dipungkiri, karena pengalaman seperti itu bukan semata-mata refleksi dari keadaan yang bersifat fisik tetapi termasuk juga emosi dan melibatkan kemauan. Lebih dari itu ia memiliki watak yang bersifat transsubjektif. Ekspresi yang bermacammacam pada pemeluk agama yang sama, merupakan bukti bahwa dilihat dari aspek potensi pada orang beragama, pengalaman beragama memang memiliki tendensi subjektif. Indikasi lain adanya unsur

\footnotetext{
12 Ibid., 27.

13 Ibid., 28.
} 
subjektivitas dalam pengalaman beragama adalah adanya fakta akan tinggi rendahnya intensitas keberagamaan orang yang seirng diungkapkan dalam bentuk kesalehan, ketakwaan, ketaatan dan lainlain. "Hadirnya" Tuhan pada seseorang akan memperoleh tanggapan berbeda-beda. Kalangan sufi atau para mistikus dari berbagai agama adalah contoh orang yang memiliki kedalaman pengalaman beragama yang berbeda dengan kebanyakan orang. Mereka ini dipandang sebagai orang-orang yang memiliki kedekatan dengan Tuhan. ${ }^{14}$

Wujud perbedaan pengalaman beragama antara satu manusia dengan yang lain menjadikan perbedaan beberapa kalangan. Ada yang menolak keberadaan pengalaman beragama, ada pula yang mengakui baik yang menyatakan tidak dapat diketahui maupun yang berpandangan bahwa pengalaman beragama tersebut dapat diketahui melalui kriteria-kriteia tertentu atau indikator tertentu. Namun terlepas dari perbedaan tersebut, pada hakikatnya pengalaman mengenai "realitas lain" tersebut dapat ditemukan dalam kenyataan sehari-hari pada masyarakat mulai dari yang masih primitif sampai yang maju, baik yang tercermin dari perilaku individual maupun kolektif kehidupan bersama. Pengalaman beragama tersebut dapat diamati dari berbagai kriteria sehingga ia bukan hanya pengembangan emosi, kemauan, hasrat, dan prasangka sosial. ${ }^{15}$

Terdapat empat kriteria untuk mengetahui pengalaman beragama, yaitu: Pertama, berangkat dari asumsi bahwa pengalaman beragama itu merupakan tanggapan terhadap realitas mutlak atau respons manusia terhadap dunia spiritual, suatu realitas yang meskipun tidak dapat tertangkap dengan alat indrawi, dia ada dan senantiasa serta "mengesankan dan menantang" umat beragama. Dia adalah realitas gaib, yaitu Tuhan yang senantiasa dirasakan kehadiran-Nya oleh orang-orang beragama. Pengalaman beragama sebagai tanggapan manusia terhadap Tuhan tersebut akan mencakup empat hal. ${ }^{16}$ (1) Adanya tingkat-tingkat kesadaran seperti pemahaman dan konsepsi mengenai Tuhan yang secara teknis disebut dengan teologi; (2) Adanya "pertemuan" antara manusia dengan Tuhan yang telah dialami oleh banyak orang sepanjang masa. Karen Amstrong menggunakan istilah homines religiose untuk menunjukkan bahwa di samping makhluk berpikir (bomo sapiens), manusia juga makhluk

\footnotetext{
14 Ibid.

${ }^{15}$ Ibid., 29.

16 Ibid., 30.
} 
beragama yang telah dibuktikan oleh kenyataan sepanjang waktu; (3) Adanya penghayatan terhadap tuhan berupa hubungan dinamis dalam bentuk "panggilan" dan "tanggapan" (call and response) yang dihayati umat beragama sebagai misteri yang dahsyat dan memukau. Akibat adanya unsur yang memukau maka umat beragama sepanjang sejarahnya senantiasa ingin mengadakan hubungan dengan Tuhan itu; (4) Adanya watak yang bersifat situasional, artinya pengalaman beragama tersebut harus dipandang dari konteks tertentu. Kenyataan ini sejalan dengan adanya penjelasan pengalaman beragama dari konteks yang berbeda-beda. Dalam pemikiran Abū Ḥāmid al-Ghazālī (w. 1111) dikemukakan kondisi iman seseorang yang selalu mengalami pasangsurut sesuai dengan situasi yang melingkupi seseorang.

Kedua, berangkat dari totalitas manusia dalam memberikan tanggapan terhadap Tuhan yang ternyata bukan hanya sekadar pikiran, perasaan, atau kehendak saja. Dengan kata lain dapat dikatakan bahwapengalaman beragama merupakan suatu susunan bertingkat yangterdiri dari tiga unsur yaitu akal, perasaan, dan kehendak. Di sinilah ia berbeda dengan pengalaman-pengalaman parsial yang hanya berkaitan dengan satu bagian saja dari eksistensi manusia. Kenyataan adanya totalitas manusia dalam menanggapi Tuhan tersebut tercermin dalam keterlibatan manusia pada agama yang dipeluknya secara total menyangkut seluruh kehidupannya. Konflik horizontal bernuansa agama yang terjadi di berbagai wilayah Indonesia terjadi karena agama bagi mereka adalah segala-galanya yang harus dipertaruhkan secara totalitas. ${ }^{17}$ Pengalaman beragama akan menjadikan orang tidak hanya berorientasi pada nilai-nilai positivistik saja. Kecenderungan pada kehidupan spiritual terkadang justru mampu memberikan jalan keluar dari kesulitan hidup.

Ketiga, berangkat dari kedalaman beragama, artinya orang beragama memiliki pengalaman mendalam dalam "pertemuannya" dengan Tuhan. Intensitas pengalaman beragama tersebut terlihat pula sakralisasi perilaku-perilaku sehari-hari, sehingga banyak aktivitas duniawi terwarnai oleh spirit keagamaan seseorang. Karya sastra keagamaan semisal puisi-puisi Muhammad Iqbal dan Jalāl al-Dīn alRūmī dapat dipandang sebagai contoh dalam hal ini. Karya seni musik seringkali sangat kental dengan nuansa keagamaan seperti Rhoma Irama, Crisye, Opick, Jefri al-Bukhari, dan lain-lain yang memasukkan nilai-nilai Islam dalam lirik lagu.

17 Ibid., 31. 
Keempat, berangkat dari perbuatan nyata yang diperlihatkan oleh umat beragama, baik secara individual maupun kolektif. Dalam Islam, iman yang berupa keyakinan atau aktivitas mental itu harus ditindaklanjuti dengan bukti nyata yaitu amal dan perbuatan. Sehingga kesempurnaan iman tidak akan terlepas dari nilai sosialnya. Hubungan antara perbuatan dengan aktivitas mental (pengalaman beragama) dapat dilihat pada berbagai pemeluk agama yang perbuatannya merupakan cerminan dari agama yang dipeluknya. Ibadah dengan segala bentuknya akan menjadi sebuah isyarat akan bentuk ungkapan nyata orang beragama dari kehidupannya sehari-hari. Dalam kenyataan kehidupan, seringkali antara dua sisi tersebut tidak mampu diseimbangkan. Adakalanya seseorang yang lebih menonjol bidang pertama yakni ibadahnya, dan sedikit mengabaikan sosialnya. Namun pada saat yang lain ada juga seseorang yang lebih menonjolkan atau mengutamakan sisi sosialnya, namun kurang memperhatikan sisi ibadahnya. Sehingga dari kondisi kedua jenis orang tersebut dapatlah dinyatakan bahwa sebenarnya memang kurang jelasnya batas antara yang sakral dan yang profan.

Hubungan antara yang sakral dan yang profan sangat erat dan tidak bisa dikesampingkan satu dengan yang lain. Yang sakral membutuhkan untuk diwujudkan dengan yang profan, sedangkan yang profan merupakan pengejawantahan dan bukti dari yang sakral tersebut. Adanya garis batas antara yang sakral dan yang profan berawal dari adanya kekeliruan memahami pengalamaman beragama yang seolah-olah hanya berada pada dunia batiniah dan seolah-olah duniawi merupakan bidang garapan manusia yang tak ada hubungannya sama sekali dengan agama.

Dari keempat kriteria tersebut dapatlah dijadikan sebagai titik tolak untuk membedakan antara pengalaman agama murni dan pengalaman non-agama, dapat pula dijadikan sebagai proposisi untuk menyatakan bahwa pengalaman beragama adalah sesuatu yang memiliki watak universalitas yang tidak terbatas oleh ruang dan waktu atau dengan kata lain tidak terbatas pada agama tertentu pada masa tertentu pula. Ia merupakan ungkapan rasa ketuhanan yang dimiliki setiap orang yang disebut dengan Sensus Numinis, atau dengan kata lain ungkapan rasa ketuhanan yang terdapat di mana-mana. ${ }^{18}$

Watak universalitas dari pengalaman beragama tersebut dalam pandangan seorang antropolog Bronisław Malinowski dalam

18 Ibid., 35. 
tulisannya Magic, Science and Religion and Other Essays, ia menyatakan bahwa betapapun primitifnya manusia, tidak akan dijumapai sekelompok orang yang tanpa agama atau magis. Hal senada juga diungkapkan oleh Bergson ketika menyatakan bahwa tidak ada masyarakat yang tanpa agama. ${ }^{19}$ Demikianlah universalitas pengalaman beragama ketika dianalisa dari sudut pandang orang yang mengalaminya.

Dilihat dari sudut pandang Tuhan, maka ada tiga aspek keuniversalan Tuhan. Pertama, sifat misterius pada Tuhan. Pengalaman beragama yang dialami oleh manusia sepanjang sejarahnya sebenarnya berhubungan dengan sesuatu yang bersifat misterius yang hanya dapat diketahui melalui pemahaman terhadap fenomena kosmos. Sifatnya yang senantiasa diselimuti oleh misteri tersebut mengundang upayaupaya spekulatif dalam mendekati Tuhan yang dilakukan oleh umat beragama. Dalam Islam misalnya, upaya untuk memahami Tuhan telah menimbulkan berbagai pandangan yang bersifat spekulatif yang tercermin dalam aneka ragam pandangan dalam dunia teologi. ${ }^{20}$

Aspek kedua, adalah adanya anggapan bahwa Tuhan merupakan sesuatu yang hidup, yang secara sederhana diperlihatkan oleh orangorang yang berkeyakinan animisme yang beranggapan bahwa dibalik benda tertentu ada kehidupan. Seorang tokoh yang bernama Smith pernah melakukan penelitian masyarakat bangsa Afrika yang menemukan adanya istilah "kekuatan vital" (force vitale) di kalangan mereka. Tuhan yang "hidup" tersebut di samping bersifat transenden (karena hakikatnya yang tidak empiris) juga bersifat imanen yang berarti bukan sesuatu yang pasif seperti anggapan kaum Deisme yang menyatakan Tuhan berada di luar alam, menciptakan alam dan setelah itu tidak mengurusi alam lagi. al-Faruqi menggunakan istilah Deus Otiosus yakni Tuhan yang menciptakan alam itu akan berjalan dengan sendirinya sesuai hukum-hukum sebab akibat atau ibarat mekanisme kerja jam. ${ }^{21}$

Ekspresi keyakinan akan Tuhan yang "hidup" itu terlihat lebih lanjut pada perilaku umat beragama yang selalu meyakini Tuhan ada di mana-mana sebagaimana ajaran Nabi yang disebut iḥsān (berbakti

\footnotetext{
${ }^{19}$ Ibid., 36.

${ }^{20}$ Keterangan lebih jelas dapat dilihat dalam Abū Zahrah dalam Tärikh Madhähib alIslämīyah, juga dalam 'Abd al-Karīm al-Shahrastānī dalam al-Milal wa al-Nị̣al, yang keduanya memberikan gambaran aneka pandangan dan mazhab teologi Islam.

21 Amin Syukur dkk, Islam Agama, 37.
} 
kepada Allah seolah-olah Dia ada di depan manusia). Atau kehidupan sufi yang tak mau sedetikpun melupakan Allah. Kalangan teolog seperti Thornton menytakan Tuhan agama Kristen adalah Tuhan yang harus bekerjasama dengan manusia karena ia adalah Tuhan yang hidup.

Aspek ketiga, yaitu adanya sifat keagungan dan kekuasaan dari Tuhan, dalam istilah Rudolf Otto disebut sebagai tramenda majesta (keagungan sekaligus kedahsyatan Tuhan) yang menimbulkan kesan pada diri manusia sebagai sesuatu yang berbeda di atas segala yang bersifat terbatas. Pengalaman beragama yang merupakan "perjumpaan" manusia dengan Tuhan tersebut memiliki potensi untuk menyatakan diri dalam ungkapan-ungkapan praktis. Hal ini disebabkan adanya pengakuan orang beragama akan kebesaran dan kedahsyatan Tuhan yang selanjutnya mengandung tanggapan manusia dalam bentuk perilaku-perilaku baik secara individual maupun sosial.

\section{KH. Sholeh dan TQN Mujaddadīyah Khālidīyah}

Pesantren yang terdiri dari berbagai elemen antara lain: Pondok, masjid, kitab kuning, santri dan kiai tidak dapat dipisahkan dengan tasawuf dan tarekat. ${ }^{22}$ Dalam tradisi pesantren, terminologi tasawuf dipergunakan untuk menyebut kajian keislaman yang menitikberatkan dimensi esoterisme Islam. Sementara itu, tarekat merupakan aspek tasawuf yang bersifat etis dan praktis. Pengamalan tasawuf dipandang lebih penting daripada aspek intelektualitas tasawuf itu sendiri. ${ }^{23}$

Zamakhsyari Dhofier menyimpulkan dua bentuk tarekat yang berlangsung dalam pesantren. ${ }^{24}$ Pertama, tarekat merupakan organisasi para sälik dan sufi yang bertujuan mendekatkan kepada Tuhan dengan metode yang ditetapkan. Ajaran tarekat meliputi prinsip kesempurnaan sulük, adab para murid, zikir, muräqabah, dan upacara ritual lain. ${ }^{25}$ Beberapa pesantren pernah menjadi pusat ke-murshid-an tarekat tertentu, seperti Pesantren Darul Ulum Peterongan Rejoso Jombang dan Pesantren Walisongo Cukir Diwek Jombang. Dua

22 Zulkifli, "Sufism in Java: The Role of the Pesantren in the Maintenance Sufism in Java", (Thesis--Australia National University, 1994).

23 Zamakhsyari Dhofier, Tradisi Pesantren: Studi Pandangan Hidup Kyai dan Visinya Mengenai Masa Depan Indonesia (Jakarta: LP3ES, Cet. ke-IX, 2015), 213.

${ }^{24}$ Ibid.

25 Kharisudin Aqib, Al-Hikmah: Memahami Teosofi Tarekat Qadiriyah Wa Naqsyabandiyah (Surabaya: Dunia Ilmu, 2000), 11. 
pesantren tersebut menjadi pusat kemurshidan Tarekat Qadiriyah wa Naqsyabandiyah (TQN).

Kedua, tarekat merupakan jalan menuju Tuhan yang dilakukan tidak berdasarkan metode yang ditetapkan ordo sufi tertentu. Metodenya dengan cara "kepatuhan secara ketat kepada peraturanperaturan syariat Islam dan mengamalkannya dengan sebaik-baiknya, baik yang bersifat ritual maupun sosial; yaitu dengan menjalankan praktik-praktik warak; mengerjakan amalan yang bersifat sunnah sebelum maupun sesudah sembahyang wajib dan mempratikkan riyädah." ${ }^{26}$ Dengan demikian, setiap subjek yang terlibat dalam pesantren, kiai dan santri, merupakan orang yang ahli dalam tarekat.

Kiai memiliki peran yang signifikan dalam memelihara tasawuf dan tarekat dalam pesantren. Tidak jarang para kiai adalah murshid tarekat tertentu. Ini dilakukan dalam rangka menjaga kesinambungan dengan proses awal Islamisasi yang terjadi di Asia Tenggara. Martin van Bruinessen menyebut bahwa tasawuf merupakan salah satu faktor penting dalam proses Islamisasi Asia Tenggara. Islam Indonesia hingga sekarang masih kental dengan sikap sufistik dan kegemaran kepada hal-hal yang mengandung keramat. ${ }^{27}$

Sebagai murshid TQN Mujaddadīyah Khālidīyah sekaligus pengasuh Pondok Pesantren Ngalah Pasuruan, Kiai Sholeh (lahir 1935) mempresentasikan kontinuitas tradisi tasawuf dalam pesantren sebagaimana diisyaratkan Dhofier. Bagi Kiai Sholeh, tasawuf terlahir dari Islam dan bukan terpengaruh dari luar Islam. ${ }^{28}$ Tasawuf merupakan implementasi ihsān yang fundamental dan esensial sekaligus inti ajaran Islam yang didakwahkan Nabi Muhammad. Karena itu, tasawuf dan tarekat bukan bidah yang menyalahi sunnah Nabi Muhammad dan sahabat.

Bila dianologikan, tasawuf dan syariat seperti dua sisi mata uang. Bila syariat berkutat dalam dimensi eksoterisme, tasawuf merupakan dimensi esoterime. Karena itu, tasawuf dipandang fiqh batin. ${ }^{29}$ Sejalan dengan itu, tarekat adalah jalan yang dilalui seorang sufi dalam menuju kepada Tuhan. Tarekat berpangkal pada syariat. Sebab, Dengan menukil Imam Abū 'Abd Allāh al-Dhahabī, Kiai Sholeh

\footnotetext{
${ }^{26}$ Dhofier, Tradisi Pesantren, 213.

27 Martin van Bruinessen, Kitab Kuning, Pesantren, dan Tarekat (Yogyakarta: Gading, Cet. Ke-2, 2015), 227.

28 Tim Penyusun, Sabilus Salikin (Pasuruan: Pondok Pesantren Ngalah, 2014), 2.

${ }^{29}$ Ibid., 3.
} 
menandaskan, "jika seorang ulama tidak bertasawuf, maka ia kosong. Sebaliknya, jika seorang sufi tidak mengenal syariat, maka ia tergelincir dari jalan yang lurus." 30

Tarekat berasal dari țaraqa yang mempunyai arti antara lain mengetuk. Disebut dengan tarekat karena dalam beribadah seorang sufi senantiasa mengetuk pintu hatinya dengan mengingat Tuhan. Metode inilah yang disebut Nabi Muhammad dengan tariqah hasanah (cara yang baik). ${ }^{31}$ Dengan demikian, tasawuf dan tarekat mempunyai landasan dalam al-Qur'ān dan ḥadīth.

Sebagai kiai sekaligus murshid tarekat, Kiai Sholeh mendesain pesantrennya sebagai institusi pendidikan Islam sekaligus pesulukan. Lembaga pendidikan yang berada di bawah naungan Pondok Pesantren Ngalah, antara lain: RA Darut Taqwa, MI Darut Taqwa, MTs Darut Taqwa, SMP Bhineka Tunggal Ika, MA Darut Taqwa, SMA Darut Taqwa, SMK Darut Taqwa dan Universitas Yudharta, mengikuti kurikulum yang ditetapkan pemerintah. Dalam waktu bersamaan, semua subjek dalam pesantren terlibat dalam ritual tarekat.

Beberapa kegiatan tarekat dalam pesantren ini terlihat dengan adanya pengajian Selosoan (setiap hari selasa). Pengajian ini disebut khusüsiyah jam'iyah. Pengajian ini diikuti oleh sekitar 300-an jemaah. Dalam pengajian ini, Kiai Sholeh bertindak sebagai guru murshid. ${ }^{32}$ Selain itu, setiap bulan mengadakan pengaiian Dzikrul Ghafilin yang dihadiri sekitar 3000-an jemaah dari berbagai daerah di Jatim. Kiai Sholeh mengajak jemaah dengan membaca wirid yang terdapat dalam kitab manāqib Shaykh 'Abd al-Qādir al-Jìlānī, Manāqib Nūr al-Burbān dan kitab yang ditulis Gus Miek Ploso Kediri, Dhiker al-Ghäfilinn. Kiai Sholeh memenuhi kriteria guru murshid bukan sekadar karena alim, warak dan zuhud, melainkan pula secara nasab masih bersambung dengan Nabi Muhammad. Legitimasi personal ini menjadi salah satu hal yang terpenting dalam dunia tarekat.

\footnotetext{
30 Ibid., 7.

${ }^{31}$ Ibid., 9.

32 Muhammad Muntahibun Nafis, Pesantren Pluralis: Peran Pesantren Ngalah dalam Mengembangkan Nilai-Nilai Pruralisme di Tengah Masyarakat yang Multikultural (Yogyakarta: Pustaka Insan Madani, 2017), 136.
} 


\section{Islam Rahmah li al-'Ālamīn dan Kabeh Dulur}

Kiai Sholeh mendirikan pesantren Ngalah dengan visi membentuk santri yang memegang teguh Islam rahmah li al- 'alamin. ${ }^{33}$ Ini didasarkan atas kenyataan eksistensi Islam yang mengalami berbagai gejolak. Islam dibajak beberapa kelompok atau "oknum" yang tidak bertanggung jawab. Berbagai aktivitas maupun respons telah mendiskreditkan Islam di mata dunia. Fundamentalisme, ekstremisme, radikalisme, rasisme, bahkan sampai terorisme mengakibatkan Islam sebagai agama welas asib (kasih sayang) tercoreng. Oknum Islam ini dengan mudah menuduh kelompok lain sebagai sesat, kafir, bahkan calon penghuni neraka. Razia hingga anarkisme yang berbau keagamaan muncul karena klaim kebenaran dirinya atas orang lain bahkan agama lain.

Ragam isu keagamaan sangat mudah dipolitisir dan dapat berakibat fatal bagi keharmonisan kehidupan bermasyarakat. Berbagai tindakan kekerasan dan kejahatan, atau bahkan peperangan yang berkelanjutan, dapat terjadi akibat politisasi isu yang berkaitan atau dikait-kaitkan dengan agama. Oleh karena itu, Islam sejak awal menegaskan tentang prinsip penjaminan terhadap hak kebebabasan beragama bagi setiap pemeluknya. Sebuah prinsip dasar untuk terciptanya masyarakat yang sehat. Dengan prinsip ini, hak dasar setiap anggota masyarakat dapat terjamin dengan baik sehingga tercipta kehidupan yang saling menghargai dan harmonis. ${ }^{34}$

Sekalipun semenjak awal Tuhan menegaskan bahwa agama yang benar adalah Islam (Āl 'Imrān [3]: 19 dan 85), namun dalam rangka menegakkan rahmah li al-älamin, Islam mengakui entitas agama lain dan menghormati pemeluk agama untuk melakukan dan menjalankan ibadah dan kepercayaan masing-masing. Islam tidak pernah memaksa seseorang untuk masuk Islam. Karena keimanan seseorang hanya dapat diterima bila dilakukan dengan tulus, tanpa ada sedikitpun pemaksaan. Iman tidak lahir dari pemaksaan. Kebenaran Islam sudah sangat jelas bagi siapa pun yang menginginkan petunjuk agama yang didakwahkan Nabi Muhammad ini.

\footnotetext{
33 Ibid., 179.

${ }^{34}$ M. Abdul Kholiq Hasan, "Menggagas Konsep Masyarakat yang Sehat; Menurut al-Qur'an”, Jurnal Kontemplasi, Vol. 1 No. 2 (2013), 275-276.

35 Muhạmmad Sayyid Țanțāwī, al-Tafsìr al-Wasit li al-Qur'ān al-Karim, Vol. 1 (Kairo: Dār Nahḍat Miṣr li al-Ṭibā'ah wa al-Nashr wa al-Tawzī', 2010), 473.
} 
Tuhan berfirman dalam kitab suciNya, "Dan jikalau Tuhanmu menghendaki, tentulah beriman semua orang yang di muka bumi seluruhnya. Maka apakah kamu (hendak) memaksa manusia supaya mereka menjadi orang-orang yang beriman semuanya?"36 Firman Tuhan lain menegaskan, "Tidak ada paksaan untuk (memasuki) agama (Islam); sesungguhnya telah jelas jalan yang benar daripada jalan yang sesat." ${ }^{\text {,37 }}$ Menurut Ibn Kathīr, ayat ini turun berkaitan dengan sikap salah satu sahabat Anshar yang ingin memaksa putranya yang beragama Kristen agar memeluk Islam. ${ }^{38}$ Tentu prinsip ini berlaku umum walaupun sebabnya turunnya ayat tersebut bersifat khusus. Sebagaiamana diatur dalam kaidah tafsir al-Tbrah bi 'umüm al-laf za la bi khusus al-sabäb, yang menjadi dasar adalah keumuman lafal ayat, bukan kekhususan sebab turunnya ayat tersebut.

Sepanjang sejarah peradaban Islam, tidak ada bukti terhadap pemaksaan penduduk untuk memeluk Islam. Prinsip ini tidak hanya dalam dogma semata, melainkan pula ketika Nabi Muhammad bertindak sebagai pemimpin umat telah menuangkan dalam aturan negara yang dikenal dengan Piagam Madinah. Di antara salah satu isinya adalah mengatur hak dan kewajiban bagi setiap pemeluk agama. Begitu pula pada masa para sahabat, pemeluk agama selain Islam diberikan kesempatan untuk menunaikan syiar keagamaan secara bebas dan aman dengan mendapatkan jaminan dari undang-undang. ${ }^{39}$ Di sisi lain, Islam bahkan melarang umatnya menghina ritual agama lain seperti yang termaktub dalam Q.S. al-An'ām [6]: 108.

Berkaitan interaksi sosial antar-pemeluk agama, ayat al-Qur'ān secara tegas menyatakan, "Allah tidak melarang kamu untuk berbuat baik dan berlaku adil terhadap orang-orang yang tiada memerangimu karena agama dan tidak (pula) mengusir kamu dari negerimu. Sesungguhnya Allah menyukai orang-orang yang berlaku adil." 40 Bahkan terhadap musuh sekalipun, al-Qur'ān tetap memperintahkan untuk berbuat adil terhadap mereka. Allah berfirman, "Dan janganlah sekali-kali kebencianmu terhadap sesuatu kaum, mendorong kamu untuk berlaku tidak adil. Berlaku adillah, karena adil itu lebih dekat

\footnotetext{
${ }^{36}$ Q.S. Yūnus [10]: 99.

${ }^{37}$ Q.S. al-Baqarah [2]: 256.

${ }^{38}$ Ibn Kathīr, Tafsìr al-Qurān al-'Ažim, Vol. 1 (t.t.: Dār al-Ṭaybah, 1999), 682.

39 Yūsuf al-Qaraḍ̄āì, Khitabunā al-Islāmì fì 'Assr al-'Awlamah (Kairo: Dār al-Shurūq, 2008), 191.

${ }^{40}$ Q.S. al-Mumtahanah [60]: 8.
} 
kepada takwa. Bertakwalah kepada Allah, sesungguhnya Allah Maha Mengetahui apa yang kamu kerjakan." 41 Dalam hadìth yang diriwayatakan al-Khațīb dengan sanad hasan, Nabi Muhammad bersabda, "Barangsiapa menyakiti orang dhimmi, maka aku akan menjadi seterunya. Siapa yang aku menjadi seterunya dia pasti kalah di hari kiamat."

Islam mengajarkan konsep kebersamaan, kesejahteraan, kerukunan, kedamaian, dan kebahagiaan. Islam menghendaki adanya tatanan masyarakat yang kondusif, baik untuk tujuan pribadi maupun masyarakat luas. Islam tidak pernah mengajarkan untuk saling merugikan satu sama lainnya, bahkan memberikan ruang gerak ekslusivisme dan radikalisme berkembang di masyarakat. Islam sangat mengecam adanya klaim kebenaran sepihak yang menjadikan seseseorang atau sekelompok orang dengan mudah menghakimi orang lain. Fleksibelitas dan dinamisasi menjadi unsur penting dalam ajaran Islam. Walaupun demikian, terkadang penganut Islam sendirilah yang menjadikan Islam kaku, statis, dan tidak mampu mengakomodir kemajuan dunia yang terus berkembang.

Islam diturunkan di muka bumi ini mengemban misi mulia untuk seluruh umat manusia, tidak hanya untuk orang-orang yang memeluk agama Islam semata. Misi tersebut diwujudkan Nabi Muhammad dengan menyampikan risalah Tuhan. Nabi Muhammad telah banyak memberikan contoh riil bagaimana menata dan menciptakan tatanan masyarakat yang berkeadilan, menjunjung tinggi nilai-nilai kemanusiaan, kesetaraan, toleransi tanpa adanya deskriminasi dan marjinalisasi. Ia telah memiliki formulasi tersendiri dalam menjalankan tugasnya baik selaku pimpinan agama, maupun pimpinan masyarakat.

Misi yang diemban Muhammad tersebut sering didengungkan banyak kalangan dengan misi agama rạmah li al-älamin. Hal ini termaktub dalam Q.S. al-Anbiyā' [21]: 105-109:

Dan sungguh telah kami tulis dalam Zabur sesudah (Kami tulis dalam) Lauh Mahfudz, bahwasannya bumi ini dipusakai hambahamba-Ku yang sholeh. Sesungguhnya (apa yang disebutkan) dalam (surat) ini, benar-benar menjadi peringatan bagi kaum yang menyembah (Allah). Tiadalah Kami mengutus kamu, melainkan untuk (menjadi) rahmat semesta alam. Katakanlah: "Sesungguhnya yang diwahyukan kepadaku adalah: "Bahwasannya Tuhanmu adalah Tuhan yang Esa. Maka hendaklah kamu berserah diri (kepada-

${ }^{41}$ Q.S. al-Mā’idah [5]: 8. 
Nya)". Jika memang berpaling, maka katakanlah: "Aku telah menyampaikan kepada kamu sekalian (ajaran) yang sama (antara kita) dan aku tidak mengetahui apakah yang diancamkan kepadamu itu sudah dekat atau masih jauh".

Dua ayat tersebut memberi tuntunan bahwa Islam mengajarkan prinsip agama untuk semuanya, bukan agama untuk orang, kelompok dan kalangan tertentu saja. Konsep tersebut adalah konsep agama rahmah li al-älamin. Konsep Islam sebagai rahmat Tuhan bagi seluruh umat manusia memang tidak secara eksplisit disebutkan dalam alQur'ān. al-Qur'ān menyebut secara eksplisit rạmmah li al-'álamin dengan tujuan mulia tersebut adalah keterutusan Muhammad. Tetapi, karena Islam adalah agama yang diemban oleh Muhammad dan wujud nyata keterutusannya, terbangunnya konsep tersebut dalam Islam memiliki pondasi dasar yang kuat rạ̣mah li al-álamin. Pertanyaan selanjutnya adalah apa atau bagaimana sebenarnya konsep rahmat bagi seluruh umat, mengapa keterutusan Muhammad disebut dengan demikian, dan bagaimana seharusnya fungsi rahmat tersebut dijalankan dan diwujudkan oleh umat Islam?

Kata rahmat berasal dari bahasa Arab al-rabmah yang berarti kelembutan hati dan kecenderungan yang menyebabkan pengampunan dan perbuatan memberikan kebaikan. ${ }^{42}$ Al-rahmah juga diartikan dengan kebaikan (anugerah) dan kenikmatan. Dengan demikiam keterutusan Muhammad dimaksudkan sebagai wujud kasih sayang Tuhan atau anugerah-Nya kepada umat manusia. Nabi Muhammad diutus demi kebaikan umat manusia yang sebelumnya hidup dalam kebodohan; menghabiskan waktu dengan tindakan yang didasarkan atas keinginan nafsu, saling membunuh, memuja bendabenda, menindas yang lemah, merusak lingkungan, tidak bertanggungjawab dan sebagainya. Segala tindakan tersebut tidak memanusiakan manusia atau dengan kata lain tidak sesuai dengan martabat manusia, sehingga mengakibatkan belas kasihan Allah kepada ummat dengan mengutus para utusan kepada manusia. Tugas utama para utusan tuhan adalah membawa umat manusia menuju jalan yang semestinya mereka tempuh, yakni jalan yang sesuai dengan hakikat keberadaan manusia. ${ }^{43}$

\footnotetext{
${ }^{42}$ Louis Ma'luf, al-Munjid fi al-Lughah (Beirut: Dār al-Mashriq, cet. XXIV, 1969), 253.

43 Machasin, Islam Dinamis Islam Harmonis: Lokalitas, Pruralisme, dan Teroisme (Yogyakarta: LKiS, 2012), 224-225.
} 
Menggunakan pertimbangan nalar dan mengikuti kata hati dalam menentukan tindakan yang hendak diwujudkan dan tidak mengikuti hawa nafsu merupakan salah satau elemen yang penting dalam kehidupan manusia. Manusia merupakan makhluk yang secara fisikbadaniah termasuk dalam jenis hewan, namun ada padanya satu hal yang membedakannya dari hewan, yakni roh yang ditiupkan Allah kepadanya. Dengan adanya roh itu, semestinya manusia menjalani kehidupan yang lebih tinggi dari hewan. Dengan itu, manusia memegang amanah Allah, menjadi wakil-Nya di atas bumi. Amanah yang dipikulnya itu musti dipertanggungjawabkan di hadapan-Nya kelak di hari akhir. Dengan arti lain bahwa manusia harus bertanggung jawab atas semua kehidupannya. Kesadaran atas tangggungjawab inilah yang ditekankan oleh al-Qur'ān dalam berbagai redaksi, di antaranya: "percaya kepada Allah dan hari akhir", "setiap perbuatan manusia tercatat dalam catatan yang cermat", "barangsiapa berbuat kebaikan seberat dharrah (atom, biji sawi), ia tentu akan melihatnya". ${ }^{44}$

Tuhan mengutus Nabi Muhammad agar mengajak manusia untuk memberikan makna bagi kehidupannya di dunia. Manusia diingatkan untuk tidak melihat dan mencari keuntungan jangka pendek sebagaimana diperoleh dengan mengikuti hawa nafsu, melainkan memilik tindakan yang membawa manfaat dalam jangka panjang. AlQur'ān memberikan perumpamaan dengan gambaran bagaikan buih yang akan hilang segera dan juga bagaikan logam untuk perhiasan dan alat-alat. Jalan Tuhan juga mengajak manusia untuk tidak mengikutkan keinginan badaniah, tetapi mengusahakan peningkatan spiritualitas, mengupayakan keadilan dalam kehidupan umat manusia, dan kedamaian semua orang. Peningkatan martabat manusia juga merupakan tujuan yang penting sehingga manusia tidak merendahkan dirinya dalam penghambaan, selain kepada Allah yang layak disembah.

Islam meletakkan fungsi rahmat dalam mengatur kehidupan manusia. Fungsi tersebut diambil dari tujuan Tuhan mengutus Nabi Muhammad yang eksplisit disebutkan dalam al-Qur'ān. Dengan demikian, sudah semestinya perwujudan fungsi rahmat oleh manusia tersebut didasari dan mengambil uswah yang sudah dipraktikkan Nabi Muhammad. Memberikan contoh perilaku dan kelembutan dalam bergaul serta ketegasan dalam menegakkan aturan merupakan sebuah keharusan yang dipraktikkan Nabi Muhammad. Meskipun demikian, kesungguhan Nabi Muhammad dalam berjuang menunjukkan

44 Ibid., 225. 
keinginan kuat untuk mengubah keadaaan menjadi lebih baik, tanpa ada paksaan.

Beberapa tindakan kekerasan yang dilakukan Nabi Muhammad ketika menjalankan dakwahnya setelah hijarah ke Madinah haruslah dianalisa diletakkan secara mendalam latar belakangnya. Selama 13 tahun Nabi Muhammad berusaha membuat perubahan sosial di Makkah, dan dalam upaya tersebut tidak jarang mendapat reaksi keras dan perlawanan dari kaum Quraisy. Nabi Muhammad menjadi musuh utama yang sah untuk dibunuh sebagaimana yang terjadi pada malam hijrah. Keberhasilan Nabi Muhammad menyatukan masyarakat Madinah dipandang menjadi ancaman berat bagi masyarakat Makkah. Dapat dibayangkan bahwa mereka sangat gundah karena seorang "musuh" yang berhasil lolos dari kepungan kemudian mendapat kekuatan besar di tempat lain.

Islam acapkali diidentikkan dengan kekerasan, terorisme, dan bom bunuh diri. Hal ini terjadi karena adanya sekelompok orang yang mengaku dan merasa menjadi "wakil Tuhan" di muka bumi. Mereka merasa memiliki kewenangan untuk menegakkan kebenaran dan berdakwah sesuai dengan pemikiran mereka sendiri. Padahal, kekerasan sebenarnya bukanlah ajaran Nabi Muhammad. Kekerasan yang dilakukan Nabi Muhammad pada saat itu bukan berarti Nabi Muhammad memberikan izin kepada pengikutnya untuk melakukan kekerasan. Kekerasan pada dasarnya hanya boleh dipergunakan ketika jalan-jalan perundingan dan perdamaian tertutup. Sejarah mencatat bahwa saat itu masyarakat Madinah hanya memiliki dua pilihan saja: bertahan dengan kekerasan, atau hancur lebur dan mengikuti keinginan kaum musyrikin. Pada perkembangan Islam selanjutnya, memang kekerasan masih dijumpai dipergunakan oleh beberapa penguasa ketika itu. Namun demikian, terdapat beberapa alasan yang dapat diungkapkan, yakni belum tersistemnya hukum antarnegara yang efektif, sehingga mengakibatkan kekuatan sebagai alat dominasi terhadap orang lain. Siapapun yang kuat, maka ia akan mampu menguasai orang lain, sehingga kekuasaannya akan menjadi bertambah besar.

Eksistensi kekerasan pada saat Nabi Muhammad menjadikan salah satu alasan beberapa orang untuk mengklaim bahwa mereka boleh mempergunakan kekerasan dalam dakwahnya. Bahkan tidak jarang kekerasan menjadi alat "mujarab" dalam melaksanakan berbagai misi yang menurut mereka tepat dalam menata masyarakat. 
Walaupun dalam kondisi tertentu menggunakan kekerasan, namun Nabi Muhammad tetap meletakkan berbagai batasan-batasan penggunaannya. Misalnya saja tidak diperbolehkannya membunuh orang tua, menyakiti anak-anak dan wanita, tidak boleh merusak peradaban, merusak tanaman, memerangi mereka yang sedang beribadah di tempat ibadah. Bahkan orang yang menyerah dalam peperangan pun tidak boleh diperangi lagi. Sebagai bukti sikap Nabi tersebut adalah ketika ada salah satu panglima perangnya yang membunuh orang yang sudah menyerah, Nabi memberikan ganti rugi kepada keluarga korban, begitu juga Nabi marah pada saat salah satu sahabat nabi membunuh orang yang sudah mengucapkan kalimat tauhid là iläh illā Alläh. ${ }^{45}$ Islam mengajarkan bahwa keburukan hendaknya dibalas dengan kebaikan. Memang terdapat ajaran bahwa kejahatan dapat dibalas dengan kejahatan serupa, namun hal itu tidak dianjurkan. Memafkan, menyantuni, berbuat lembut terhadap orang yang berbuat keburukan jauh lebih dianjurkan dan menjadi keutamaan bagi yang melakukannya. Manusia dianugerahi akal dan memiliki hati nurani, sehingga manusia sebenarnya dapat membedakan mana antara yang baik dan buruk. Pada saat kehilangan akal sehat, manusia untuk memaafkan dan bahkan membalas dengan perbuatan yang baik terhadap oranglain yang menyakitinya. Namun inilah ajaran Islam, sebuah nilai keutamaan dalam membangun tatanan masyarakat yang memiliki peradaban.

Dalam Islam rạmah li al-alamin itulah, Kiai Sholeh menjadikan dasar bagi pesantren. Pesantren Ngalah didirikan sebagai upaya merealisasikan dawuh ayahanda Kiai Sholeh, gek embong, gek pasar, gek masjid iku kabeh dulurmu (di jalan, di pasar, di masjid, semua itu saudaramu). ${ }^{46}$ Konsep kabeb dulur (semua saudara) tidak dibatasi dengan agama dan keyakinan tertentu. Kabeh dulur karena semua manusia adalah ciptaan Tuhan yang harus dihargai dan dimanusiakan. Kiai Sholeh mengungkap dengan bahasa sederhana, iso gembul uwong lan iso nguwongno uwong (bisa bergaul dengan orang lain dan memanusiakan orang lain). ${ }^{47}$ Seduluran tanpa memandang latar belakang sosial, politik, dan agama.

Secara aplikatif, dalam konsep kabeh dulur, Kiai Sholeh mempersilahkan pesantrennya untuk didiami (live in) santri non-

\footnotetext{
45 Ibid., 230.

${ }^{46}$ Nafis, Pesantren Pluralis, 180.

47 Ibid., 181.
} 
Muslim yang bertujuan membangun toleransi sekaligus saling memahami antar-agama dan kepercayaan. Secara internal santri nonMuslim berada di Pesantren Ngalah mempunyai tujuan, antara lain: (1) Mengenal Islam; (2) Mendalami ajaran Islam, terutama yang terkait dengan masyarakat; dan (3) Membangun dialog peradaban dengan pesantren. Di sisi lain, secara eksternal, santri non-Muslim bermaksud mengenalkan pemahaman agama mereka kepada pesantren sekaligus mempererat hubungan sosial dan nasionalisme. ${ }^{48}$ Dalam waktu yang bersamaan, Kiai Sholeh menyediakan dirinya untuk memberikan pemahaman Islam kepada penganut agama lain di tempat ibadah mereka. Bagi Kiai Sholeh, pluralitas agama tidak menjadi sekat bagi tumbuhnya seduluran. Semuanya dilakukan, sebagaimana tertulis disampul Sabil al-Sälikin, tiada tujuan lain, hanya mengharap rida Tuhan dengan cara toleran terhadap pemeluk agama liyan (the other).

\section{Catatan Akhir}

Pembahasan artikel ini menunjukkan bahwa tasawuf dan tarekat yang memahami agama dari dimensi esoterisnya mendorong sikap yang toleran terhadap pemeluk agama lain. Toleransi ini bersumber dari pemahaman mendalam tentang agama, manusia, dan alam semesta. Dalam tasawuf, agama tidak sekadar dipahami secara ritual semata, melainkan sebagai anugerah alam semesta. Karena itu, dalam beragama harus dilambari dengan sifat welas asih (rahmab) terhadap siapapun.

Sejalan dengan itu, manusia tidak dipandang berdasarkan latar belakang sosial dan agama. Sebab, semua manusia merupakan makluk Tuhan yang harus dimanusiakan. Dalam bahasa sederhana Kiai Sholeh, semua manusia merupakan kabeh sedulur. Pandangan mendalam inilah yang mendorong tasawuf mampu membangun peradaban dengan berbagai macam agama dan budaya.

Kondisi masyarakat Indonesia yang plural meniscayakan kehidupan beragama yang harmonis dan toleran dalam rangka pengamalan keberagamaan masing-masing. Salah satu upaya yang bisa dilakukan adalah membangun toleransi beragama sedini mungkin. Dalam konteks ini, maka nilai-nilai tasawuf menjadi urgen untuk diinternalisasikan karena nilai fundamen yang tertanam dalam jiwa akan mengejawantah dalam berbagai perilaku keseharian serta dalam kehidupan bermasyarakat.

48 Ibid., 185. 


\section{Daftar Rujukan}

A’la, Abd. Melampui Dialog Agama. Jakarta: Kompas, 2002.

Abdullah, M. Amin. "Menuju Pendidikan Islam Pluralis", Taswirul Afkear, edisi No 11, 9.

Abror, Robby H. Tasawuf Sosial: Membeningkan Kebidupan dengan Kesadaran Spiritual. Yogyakarta: AK Gorup- Fajar Pustaka Baru, 2002.

Aqib, Kharisudin. Al-Hikmah: Memahami Teosofi Tarekat Qadiriyah Wa Naqsyabandiyah. Surabaya: Dunia Ilmu, 2000.

Arifin, Samsul. Merambah Jalan Baru dalam Beragama: Rekonstruksi Kearifan Perenial Agama dalam Masyarakat Madani dan Pluralitas Bangsa. Yogyakarta: ITTAQA Press, 2001.

Bagir, Zainal Abidin dkk. Laporan Tabun Kebidupan Beragama di Indonesia. Yogyakarta: CRCS UGM, 2011.

Bruinessen, Martin van. Kitab Kuning, Pesantren, dan Tarekat. Yogyakarta: Gading, Cet. Ke-2, 2015.

Dhofier, Zamakhsyari. Tradisi Pesantren: Studi Pandangan Hidup Kyai dan Visinya Mengenai Masa Depan Indonesia. Jakarta: LP3ES, Cet. ke-IX, 2015.

Hasan, M. Abdul Kholiq. "Menggagas Konsep Masyarakat yang Sehat; Menurut al-Qur'an", Jurnal Kontemplasi, Vol. 1 No. 2, 2013.

Kathīr, Ibn. Tafsìr al-Qurān al-'Ažim, Vol. 1. t.t.: Dār al-Ṭaybah, 1999.

Ma'luf, Louis. al-Munjid fì al-Lughah. Beirut: Dār al-Mashriq, cet. XXIV, 1969.

Machasin. Islam Dinamis Islam Harmonis: Lokalitas, Pruralisme, dan Teroisme. Yogyakarta: LKiS, 2012.

Mulkhan, Abdul Munir. Membongkar Praktek Kekerasan: Menggagas Kultur Nir-Kekerasan. Yogyakarta: Sinergi Press, 2002.

Nafis, Muhammad Muntahibun. Pesantren Pluralis: Peran Pesantren Ngalah dalam Mengembangkan Nilai-Nilai Pruralisme di Tengah Masyarakat yang Multikultural. Yogyakarta: Pustaka Insan Madani, 2017.

Penyusun, Tim. Sabilus Salikin. Pasuruan: Pondok Pesantren Ngalah, 2014.

Qaraḍ̄wī (al), Yūsuf. Khitabunā al-Islāmì fì 'Assr al-'Awlamah. Kairo: Dār al-Shurūq, 2008.

Steenbrink, Karel. "Indonesia: Too Much Religion” Basis, No. 01-02, Januari-Februari 2004, 44. 
Sunardi, St. "Rekayasa Kerukunan Umat Beragama," Basis, No. 01-02, Januari-Februari 2004.

Syukur, Amin. dkk, Islam Agama Santun. Semarang: IAIN WalisongoRaSAIL Media Group, 2011.

Ṭanțāwī, Muḥammad Sayyid. al-Tafsìr al-W asịt li al-Qur'ān al-Karim, Vol. 1. Kairo: Dār Nahḍat Miṣr li al-Ṭibā'ah wa al-Nashr wa alTawzī', 2010.

Zulkifli. "Sufism in Java: The Role of the Pesantren in the Maintenance Sufism in Java". Thesis--Australia National University, 1994. 